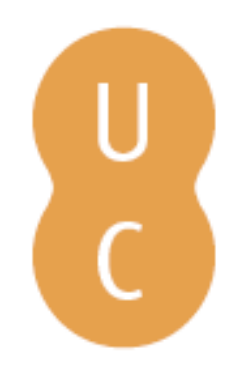

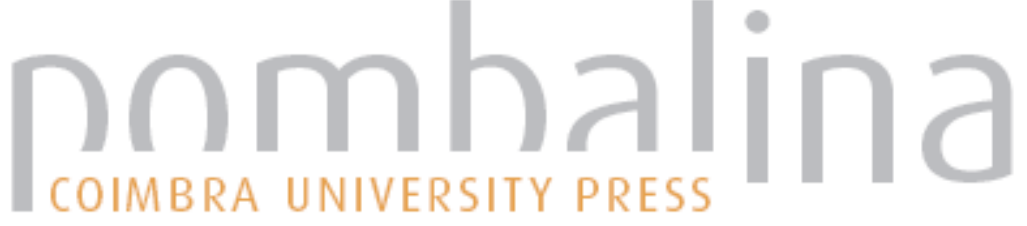

\section{Escalas do poder local: das cidades aos campos}

Autor(es): $\quad$ Silva, Francisco Ribeiro da

Publicado por: Imprensa da Universidade de Coimbra; CEFA

URL

persistente: URI:http://hdl.handle.net/10316.2/32469

DOI: $\quad$ DOI:http://dx.doi.org/10.14195/978-989-26-0439-8_3

Accessed : $\quad$ 26-Apr-2023 15:51:17

A navegação consulta e descarregamento dos títulos inseridos nas Bibliotecas Digitais UC Digitalis, UC Pombalina e UC Impactum, pressupõem a aceitação plena e sem reservas dos Termos e Condições de Uso destas Bibliotecas Digitais, disponíveis em https://digitalis.uc.pt/pt-pt/termos.

Conforme exposto nos referidos Termos e Condições de Uso, o descarregamento de títulos de acesso restrito requer uma licença válida de autorização devendo o utilizador aceder ao(s) documento(s) a partir de um endereço de IP da instituição detentora da supramencionada licença.

Ao utilizador é apenas permitido o descarregamento para uso pessoal, pelo que o emprego do(s) título(s) descarregado(s) para outro fim, designadamente comercial, carece de autorização do respetivo autor ou editor da obra.

Na medida em que todas as obras da UC Digitalis se encontram protegidas pelo Código do Direito de Autor e Direitos Conexos e demais legislação aplicável, toda a cópia, parcial ou total, deste documento, nos casos em que é legalmente admitida, deverá conter ou fazer-se acompanhar por este aviso.

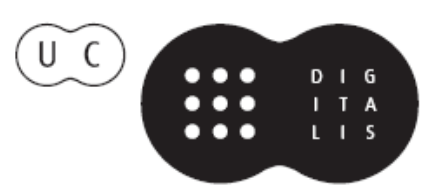


FERNANDO TAVEIRA DA FONSECA

\section{Coordenação}

O poder local em tempo de

Globalização

uma história

e um futuro

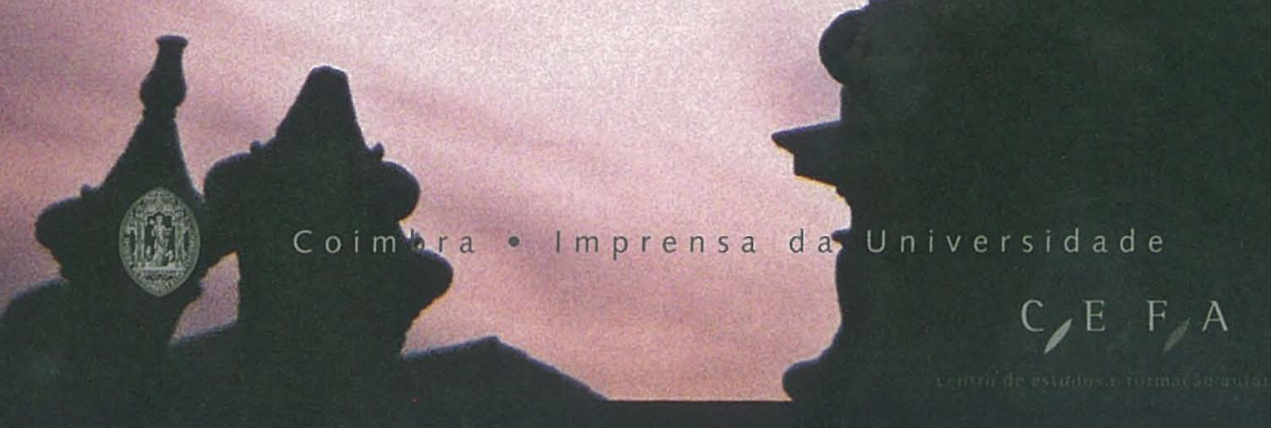


(Página deixada propositadamente em branco) 


\section{FERNANDO TAVEIRA DA FONSECA}

Coordenação

$\mathrm{O}$

poder local

em tempo

de

Globalização

uma história

e um futuro

Coimbra - Imprensa da Universidade

$C, E, F / A$ 
COORDENAÇÃo EDITORIAL

Imprensa da Universidade de Coimbra

CONCEPÇÃo GRÁfICA

António Barros

PAGINAÇÃo

António Resende

[Universidade de Coimbra]

EXECUÇÃo GRÁFICA

G.C. - Gráfica de Coimbra, Lda.

Palheira - Assafarge - Apart. 3068

3001-453 Coimbra Codex

\section{ISBN}

972-8704-32-1 (IUC)

972-8809-11-5 (CEFA)

DEPÓSITO LEGAL

229953/05

(c) JUNHO 2005, IMPRENSA DA UNIVERSIDADE DE COIMBRA 
Francisco Ribeiro da Silva

Universidade do Porto

\section{ESCALAS DO PODER LOCAL: DAS CIDADES AOS CAMPOS}

\section{1 - Introdução}

A experiência vital de cada indivíduo na sua relação com o Poder indica que ao longo da sua vida são dois ou três os níveis com que se vê enquadrado, como do mesmo modo são dois ou três os círculos dentro dos quais se desenvolve a trama institucional da sua própria existência: o sítio onde vive ou onde trabalha, a região em que se insere e o país a que pertence. Na organização do seu dia a dia é confrontado com actos reguladores que provêm das autoridades locais (Junta de Freguesia, Câmara Municipal, Comissões de Coordenação), mas nas questões mais gerais e talvez mais estruturantes as suas referências dirigem-se para o governo central ou para as suas repartições sediadas na sua cidade ou vila. Mas de muitos modos o local e o nacional interagem e estão muito longe de se definirem ou de se pretenderem como compartimentos estanques.

Acrescente-se, no entanto, que hoje em dia o quotidiano de todos nós é influenciado por forças que estão muito para além desses dois círculos. Não só porque as leis nacionais são, por vezes, derivadas de estímulos e motivações que se geram para lá das fronteiras físicas do próprio país, mas porque cada um, desde o interior do seu pequeno escritório, pode estar em contacto permanente e interactivo com o mundo inteiro. Quer dizer o global e o local cruzam-se e é em virtude da fantástica e universal possibilidade de troca de informações que um episódio insignificante acontecido numa pequena cidade, mostrado a todo o mundo, pode desencadear movimentos que o catapultam para o centro das preocupações da humanidade. Global e local interagem e o local pode de repente tornar-se global.

Mas não é neste nível que pretendo colocar o registo da minha intervenção.

Quando se fala de escalas do poder local o que é que se pretende designar? $\mathrm{Na}$ linguagem corrente hodierna, a expressão poder local é utilizada para significar a governação autárquica que, em princípio, cabe aos municípios exercer. Por conseguinte, subentende-se nela uma referência ao municipalismo. Advirta-se, no entanto, que nem os concelhos parecem monopolizar o poder local, nem a dimensão política esgota o conceito de poder local. Lembraria, por exemplo, que, entre 
outros, o poder religioso está no terreno e condiciona eventualmente outros sectores do poder.

Do mesmo modo, ao evocarmos o poder local nos séculos passados, entendemos regra geral, o poder atribuído ou exercido pelos concelhos. Mas acima e abaixo dos municípios havia outras instâncias do poder. Efectivamente os Reis de Portugal criaram e desenvolveram circunscrições outras, acima dos concelhos, de base territorial mais ou menos extensa, algumas ocasionais, outras de grande durabilidade que, a nosso ver, se podem classificar de poderes intermédios. Intermédios entre o quê? Naturalmente entre o poder do centro e o poder dos Concelhos. Algo a que António Manuel Hespanha engloba sob a designação de Administração periférica da Coroa. (1) E abaixo dos Concelhos existiam comunidades que no século XIX se inseriam no que Rodrigues Sampaio chamava «associações naturais», ou seja as famílias, as freguesias e as paróquias, ao contrário dos municípios que para ele não faziam parte do seu entendimento de associações naturais. ${ }^{(2)}$

Como quer que seja numa exposição sobre as escalas de poder local não podemos ignorar nenhuma das ditas circunscrições.

\section{2- Que circunscrições acima dos Concelhos?}

\section{1 - A Relação e Casa do Porto e o seu Governador}

Falemos primeiro das que acima rotulámos de ocasionais. É sabido que no Antigo Regime por toda a Europa se verificava uma certa sobreposição das competências de diversas instituições. Quero dizer com isto que uma instituição vocacionada para a administração da justiça podia ser superiormente encarregada ou encarregar-se de funções administrativas correntes. Com este preâmbulo pretendo trazer à discussão neste Congresso sobre Poder Local um Tribunal Superior, a Relação e Casa do Porto e afirmar que ele, não de modo permanente mas sim a espaços, constituiu uma verdadeira instância superior (hesito em classificá-la de «regional») de poder administrativo, através do seu Governador e dos Desembargadores.

(1) HESPANHA, António Manuel, As vésperas do Leviathan. Instituições e poder político Portugal - séc. XVII, Coimbra, Almedina, 1994, p. 195.

(2) OLIVEIRA, César de, História dos Municipios e do Poder Local dos finais da Idade Média à União Europeia, Lisboa, Círculo de Leitores, 1995, p.212. Excluímos do nosso quadro de referência as Províncias. Não é que as não consideremos divisões espaciais importantes e com identidade própria e historicamente muito forte mas porque nelas, durante a época moderna, não estacionou nenhuma instituição de poder de base provincial, com excepção da organização militar (séc. XVIII Governadores de armas) e séc. XVII (Feitores das Alfândegas e portos secos). 
Se atentarmos na doutrina das Ordenações Filipinas não é consagrada aí nenhuma interferência do Governador na administração concelhia. Mas que tais matérias não eram de todo afastadas das suas atribuições ressalta da prescrição legal que obrigava todos os tabeliães e escrivães dos lugares e concelhos de seu distrito a registarem em livro adequado, guardado no Tribunal, os seus sinais de pública identificação para se poderem cotejar e reconhecer as assinaturas de documentos saídos de sua lavra. ${ }^{(3)}$ Ora o distrito da Relação do Porto abrangia as três Províncias do Norte, Trás-os-Montes, Entre Douro e Minho e Beira, com exclusão da Comarca de Castelo Branco mas incluindo as correições de Coimbra e da Esgueira que alguns autores colocavam na Província da Estremadura. ${ }^{(4)}$ Trata-se de uma circunscrição que abrangia mais de um terço do território português.

Provámos no já longínquo ano de 1986 na nossa tese de doutoramento que aos Governadores da Relação foram confiadas tarefas e conferidos poderes que iam muito para além das competências normais ligadas à esfera da justiça. A resposta a problemas sociais agudos como o da pobreza e da fome (1590 e 1614), a fiscalização e mesmo a chefia dos serviços de saúde pública que normalmente cabiam ao Senado da Câmara (prevenção ou profilaxia da peste), organização da defesa militar contra a pirataria ou potenciais ataques externos, a própria autorização para um Vereador ir a banhos (1625), a fiscalização das contas do Cofre dos Crescimentos e da Imposição do Vinho, o controlo da eleição/nomeação de alguns oficiais camarários, nomeadamente os Almotacés. ${ }^{(5)}$

Do que nessa altura tínhamos dúvidas era se essa acção de supervisão administrativa se exercia apenas sobre a cidade do Porto e seu termo onde o Governador residia ou se se alargava a outras cidades e vilas colocadas sob a alçada do Tribunal. Pudemos averiguar que não só o Governador mas também alguns Desembargadores do Tribunal desenvolveram actividades de fiscalização em todo o Norte, sobretudo em dois tipos de circunstâncias: quando se declaravam situações de crise do género das que acima referimos ou quando a largueza dos programas a executar exigia alguma coordenação de pendor regional.

Lembremos alguns exemplos: em 1624 um Desembargador (Francisco de Andrade Leitão) foi enviado à vila de Caminha para inquirir sobre o desempenho suspeito do Escrivão da Alfândega local; em 1586, outro Desembargador foi desta-

(3) Ordenações Filipinas, Livro I, título I, § 44.

(4) SILVA, Francisco Ribeiro da, "O Governador da Relação do Porto: um magistrado judicial ou um delegado regional do poder régio?» in III Jornadas de Estudo Norte de Portugal Aquitânia. Actas, Porto, 1966, p. 394.

(5) SILVA, Francisco Ribeiro da, O Porto e o seu Termo (1580-1640). Os homens, as Instituições e o Poder, vol. I, Porto, Arquivo Histórico Municipal, 1988, pp. 976-977. 
cado para averiguar em Viana da Foz do Lima acerca de ocorrências locais eventualmente favoráveis às pretensões de D. António, Prior do Crato. No século XVII era normal que, próximo do fim de cada ano, um Desembargador da Relação se ausentasse para Guimarães a fim de aí fiscalizar as contas das receitas e despesas do Concelho. Será ocioso recordar que as despesas com pousada, alimentação e prendas corriam por conta os cofres concelhios? ${ }^{(6)}$

Conclusão: a partir de 1583 um novo poder supraconcelhio, o do Governador da Relação, foi-se sobrepondo ao menos em situações específicas e ocasionais aos poderes do Senado Municipal do Porto. Não admira que três anos decorridos, não obstante a honra que significava para os brios portuenses a instalação do segundo Tribunal Superior do Reino dentro de seus muros, a Câmara tenha requerido ao rei que o dito fosse transferido para outra cidade, Lisboa de preferência.

Quando acontecia que o Governador das Justiças acumulava esse ofício com o cargo de Governador das Armas (e isso aconteceu no século XVIII, por exemplo com João de Almada e Melo), prefigurava uma autoridade de amplos poderes regionais. $\mathrm{O}$ que não quer dizer que o espaço que lhe cabia em jurisdição tivesse chegado a constituir uma região administrativa. Ainda que possamos suspeitar de que a expressão «três Províncias do Norte» tenha sido usada por Lisboa para designar um espaço do Reino com alguma solidariedade pelo menos operacional. Por exemplo, em 1760 foi dado à Companhia Geral da Agricultura das Vinhas do Alto Douro o exclusivo da fabricação e comercialização da aguardente nas três Províncias do Norte, território que conserva alguma correspondência, ainda que vaga, com o da Província Eclesiástica de Braga que é uma das três em que se divide o Portugal católico.

\section{2 - Comarcas, Corregedores e Provedores}

Observemos de seguida outros círculos difundidos por todo o Reino que, criados por iniciativa régia para tornar mais eficaz e expedita a administração da justiça, acabaram por tutelar de algum modo os Concelhos. Referimo-nos às Provedorias e Comarcas, (a palavra Comarca é utilizada nas Ordenações Filipinas para designar o espaço territorial de jurisdição quer do Provedor quer do Corregedor) circunscrições distintas entre si pelas competências específicas dos seus titulares, pelo número e obviamente pelas dimensões espaciais e áreas de jurisdição. Insistimos que não se devem confundir Provedorias com Comarcas ainda que em alguns poucos casos tenha havido coincidência nos limites e até na pessoa nomeada, como eram os casos das Comarcas do Porto, Braga (após 1790), Faro e Penafiel.

(6) SILVA, Francisco Ribeiro da, «O Governador da Relação do Porto...», o.c., p. 398. 
Tempos houve em que quase coincidiam no espaço umas e outras. De facto, nos princípios do século XVII sendo 26 o número de Comarcas, ${ }^{(7)}$ provavelmente seria algo mais baixo, mas bem próximo desse, o número de Provedorias e um tudo nada mais elevado o número de almoxarifados, circunscrições fiscais - 28 ou 29. Mas nos finais do século XVIII, situando-se entre 24 e 26 o número de Provedorias, ${ }^{(8)}$ crescera muito o das Comarcas, parte substancial das quais surgiu na sequência da lei da abolição das Donatarias de 1790 que, como veremos, transformava tendencialmente as antigas Ouvidorias senhoriais em Comarcas régias. ${ }^{(9)}$ Em 1825, o seu número já era de $44 .{ }^{(10)}$

Mas mais do que pela quantidade e pela extensão, as duas circunscrições distinguiam-se pelas competências específicas dos seus magistrados, respectivamente Provedores e Corregedores.

\subsection{1 - Provedores}

As Ordenações Filipinas que guardam o principal texto de referência sobre o estatuto dos Provedores (Livro I, tit. 62), acrescentado por leis avulsas dos monarcas posteriores, principalmente de D. José, de Dona Maria I e de D. João VI, atribuem genericamente aos Provedores das Comarcas poderes de controlo e vigilância na área dos bens da Coroa e das finanças municipais, seguindo direcções específicas que aqui não importa pormenorizar. A sua jurisdição estendia-se também à administração de bens particulares deixados por testamento em benefício de terceiros que tanto podiam ser órfãos como instituições de caridade e legados pios deixados como penhor e garantia de sufrágios. Por conseguinte, são agentes régios encarregados da fiscalização de rendas e de bens públicos da Fazenda ou dos Concelhos, mas também são legalmente vocacionados para a protecção a indivíduos em situação fragilizada. Por essa via, a sua acção, mais do que a de qualquer outro Magistrado, interferia no quotidiano das pessoas.

(7) Em 1629 foram contactados os Corregedores das seguintes comarcas: Viana, Ponte de Lima, Miranda, Guimarães, Torre de Moncorvo, Vila Real, Porto, Lamego, Pinhel, Esgueira, Viseu, Guarda, Coimbra, Castelo Branco, Leiria, Tomar, Portalegre, Santarém, Alenquer, Setúbal, Évora, Elvas, Estremoz, Beja, Lagos e Tavira. (SILVA, Francisco Ribeiro da, O Porto e o seu Termo (1580-1640). Os Homens, as Instituições e o Poder, II vol., Porto, 1988, p. 997.

(8) MARQUES, A. H. de Oliveira, Breve História de Portugal, Lisboa, 1995, p.346. O Almanaque Português de 1825 enumera as seguintes Provedorias: Algarve, Aveiro, Beja, Braga, Castelo Branco, Coimbra, Elvas, Évora, Guarda, Guimarães, Lamego, Leiria, Lisboa(?), Miranda, Moncorvo, Ourique, Penafiel, Portalegre, Porto, Santarém, Setúbal, Tomar, Torres Vedras, Viana do Minho e Viseu.

(9) Não foi o caso da de Alcobaça nem da de Penafiel, criadas em 1775

(10) Almanach Portuguez, Lisboa, 1825. 
Como superintendente das «obras, órfãos, capelas, hospitais, confrarias, albergarias, gafarias», como aparece escrito em quase todas as cartas de nomeação, cabia-lhes fiscalizar a execução dos testamentos e fazer cumprir as vontades dos defuntos, especialmente as relativas a bens ou fundações para sufrágio das almas.

Pertencia-lhe igualmente cuidar dos interesses dos órfãos, obrigando os Juízes do mesmo nome a cumprirem o estipulado na lei e recebendo os agravos e apelos das suas sentenças.

Outro sector específico da sua providência eram os hospitais e a assistência aos doentes neles internados. Até tomavam contas todos os anos aos oficiais das poderosas Confrarias das Misericórdias. ${ }^{(11)}$ Nos inícios do século XIX, porém, uma parte dessas competências passou para a Intendência Geral da Polícia. (12)

Ao nosso objectivo interessa sobretudo sublinhar o primeiro campo apontado o da relação com as Câmaras - que, aliás, está longe de ser o mais importante no conjunto dos artigos que definem as suas competências legais. Na verdade, aquele título não consagra mais que 11 artigos (num conjunto de 80 ) às atribuições directas dos Provedores na esfera da administração concelhia.

Nesse domínio, o primeiro e principal cuidado do Provedor seria o de garantir a justa e segura arrecadação das terças régias em tempo adequado e nos valores correctos. Por isso, era mandatado para, anualmente, inspeccionar os livros das rendas do Concelho e obrigar o Tesoureiro municipal a entregar ao recebedor das terças o que a elas pertencesse. $O$ peso que o legislador conferia a esta obrigação está subentendido na pena cominada ao Provedor, isto é, no caso de a arrecadação se perder por sua negligência, seria compelido pelos seus superiores hierárquicos (os Desembargadores do Paço) a repor do seu bolso a importância em falta. Mas, para além disso, deveria fiscalizar o uso que se fazia dos restantes dois terços dos dinheiros concelhios. Despesas que não fossem em prol do bem do Concelho não seriam aprovadas. E as verbas despendidas em subsídios, que por altura das festas se atribuíam um pouco por toda a parte às individualidades investidas em autoridade (inclusive os mesmos Provedores), só seriam levadas em conta se para elas houvesse provisão régia a autorizar. Caso contrário, os Vereadores teriam que restituir do seu as verbas ilegitimamente levantadas ou, no caso de culpa do Provedor, seria ele próprio mais uma vez a repor.

Por conseguinte, é a lei fundadora que obriga os Provedores à vigilância cuidada e à tutela apertada dos Senados Municipais no que tocava às finanças e aos bens dos

(11) Arquivo Nacional da Torre do Tombo, Livro $2^{\circ}$ de Leis, fl. 66 (alvará de 22 de Janeiro de 1604), confirmado e ampliado pelo alvará de 18 de Outubro de 1806. As rendas dos hospitais anexos às Misericórdias estavam sob a sua fiscalização (lei de 13 de Janeiro de 1615).

(12) Alvará de 18 de Outubro de 1806. 
concelhos. Posteriormente, a missão dos Provedores foi facilitada pela lei de 1766 que ordenou novas e mais transparentes formas de organização da contabilidade municipal.

Em que sentido é que funcionaram as práticas de tutela dos Provedores? Embora não sejam abundantes as monografias disponíveis sobre estas matérias, os estudos publicados permitem estabelecer o seguinte: a actuação dos Magistrados pautava-se por uma cada vez mais apertada vigilância e controlo das finanças municipais, de modo especial sobre as despesas, mas sem deixar de olhar pela optimizaçăo da arrematação e cobrança das receitas. Concretamente, no que se refere às despesas, os abusos mais comuns e mais antigos que deviam refrear diziam respeito à concessão de propinas e subsídios não autorizados e ao pagamento de contas para as quais não havia sido solicitada a permissão régia prevista nas Ordenações. A fiscalização das receitas passava pela prevenção de nepotismos e conluios indesejáveis mas frequentes entre arrematantes na fase da adjudicação dos bens ou das rendas e pela vigilância da eficácia da recolha na fase da cobrança e isto já em épocas recuadas como esclarecemos, há uns anos, na nossa dissertação doutoral.(13)

Do mesmo modo, protegiam os bens dos concelhos devendo tirar devassa dos descaminhos desses bens se os contratadores das terças Iho requeressem ${ }^{(14)} \mathrm{e}$ ordenando a restituição dos que andassem sonegados ${ }^{(15)}$ bem como dos maninhos e baldios que Donatários, Igrejas ou Mosteiros possuíssem sem o respectivo título, de nada valendo neste caso a posse imemorial.(16)

Sempre foram na Província os zeladores e administradores por excelência dos bens da Coroa.

Até 1790, dadas as isenções de correição de muitas terras de Donatários, a Monarquia Absoluta teve interesse estratégico em reforçar o prestígio dos Provedores, pois, face aos Donatários, não podia recorrer aos Corregedores uma vez que, por privilégios antigos, estes não podiam entrar nelas. Aliás, já nos inícios do século XVII os Provedores haviam sido encarregados de, nas devassas anuais, vigiar e denunciar casos de Donatários que casassem sem prévia licença do Rei.(17) E em pleno pombalismo foi necessário esclarecer que, quanto às Câmaras dos Donatários, os Provedores podiam para elas passar ordens mas só para aquelas para onde os Corregedores as não mandassem e que na qualidade de Contadores da Fazenda Real, não se Ihes poderiam colocar entraves para entrarem em qualquer lugar, por

\footnotetext{
(13) SILVA, Francisco Ribeiro da, O Porto e o seu Termo...oc., pp. 983-984.

(14) Alvará de 10 de Fevereiro de 1654.

(15) Alvarás de 13 de Outubro de 1666 e de 23 de Julho de 1766.

(16) Provisão de 26 de Novembro de 1766.

(17) Lei de 13 de Dezembro de 1616.
} 
mais privilegiado que fosse. ${ }^{(18)}$ A lei da abolição das Donatarias derrubou todos os obstáculos que ainda pudessem subsistir quanto ao seu direito de entrada nessas terras. Pensámos, aliás, que a abolição das Donatarias deixou de justificar a existência de Provedores.

Daí em diante a Magistratura sobreviverá ainda até 1830, altura em que é extinta, mas cada vez mais a sua esfera de acção se exerce dentro dos parâmetros fixados pelo Ordenações. Mesmo aí vão ter que saber viver com a concorrência dos Corregedores com os quais aqui e além vão surgir inevitáveis conflitos de competência.

Pelo que ficou dito, impõe-se a conclusão de que eram magistrados de grande poder e prestígio institucional. Mas o Absolutismo, não obstante as práticas de venalidade e hereditariedade dos ofícios (que, aliás, se limitaram a cargos bem menos importantes), não favoreceu a criação de Oficiais intocáveis. Nem os Provedores o eram, não obstante as Ordenações Filipinas não os incluírem no rol dos magistrados obrigados a dar residência o que não quer dizer que dela fossem para sempre dispensados. ${ }^{(19)}$

A acção tutelar dos Provedores, nos finais do século XVIII, cujo símbolo do poder era a vara branca, ${ }^{(20)}$ mostrou-se determinante nos municípios do Noroeste Peninsular, "sobretudo nas terras de senhorio particular»,(21) sendo igualmente sensível noutros municípios estudados, de que destacamos o de Montemor-o-Novo. ${ }^{(22)}$

\subsection{2 - Corregedores}

Tal como acontecia com os Provedores, o documento-referência dos Corregedores encontra-se nas Ordenações Filipinas (Liv. $1{ }^{\circ}{ }^{\circ}$ tit. 58) acrescentado ou explicitado pelo regimento que era dado em cada nomeação e enriquecido estrategicamente por legislação avulsa posterior.

As suas atribuições exerciam-se tanto no âmbito judicial como no da administração civil propriamente dita. A promoção da justiça era provavelmente a mais marcante

(18) Provisão de 12 de Outubro de 1769 e instrução de 4 de Setembro de 1773.

(19) De facto o decreto de 24 de Setembro de 1623 subentende que a sua promoção não era possível sem despacho favorável na residência.

(20) Portaria de 25 de Outubro de 1747.

(21) CAPELA, José Viriato, O Minho e os seus Municipios. Estudos Económico- administrativos sobre o município português nos horizontes da Reforma Liberal, Braga, 1995, p.111.Do mesmo Autor ver ainda O Município de Braga de 1750 a 1834 . O Governo e a Administração económica e financeira, Braga, 1991,pp. 178-179; A Câmara, a nobreza e o povo do Concelho de Barcelos, Barcelos, 1989, pp. 235-237.

(22) Ver FONSECA, Teresa, Relações de Poder no Antigo Regime. A administração municipal em Montemor-o-Novo (1777-1816), Montemor-o-Novo, 1995, p.125. 
das suas competências e era sobre ela que devia incidir a sua primordial atenção ao chegar ao lugar de exercício, dando protecção judicial especial aos menos poderosos e atendendo diligentemente às queixas dos injustiçados. Nas cabeças de Comarca onde tinham sua morada habitual, concediam audiência duas vezes por semana.

E nas correições que anualmente eram obrigados a fazer pelos lugares da Comarca, indagariam acerca de conluios e provas falsas para corrigir sentenças eventualmente injustas e proceder contra juízes corruptos. Para além de denunciar protecções ilegítimas dos Grandes a criminosos e malfeitores, poderia, por acção nova, conhecer alguns feitos em que os juízes da terra fossem considerados suspeitos. Já no fim do nosso período, foi-lhes cometida mesmo a vigilância sobre a conduta dos Juízes de Fora no que tocava à observância das leis contra o monopólio dos gados. ${ }^{(23)}$

Outra competência socialmente importante do Corregedor, antes e depois da criação da Intendência da Polícia, era a manutenção da ordem pública, superintendendo e coordenando a acção dos agentes tradicionais da ordem, quais eram os alcaides pequenos, os meirinhos, os quadrilheiros, fiscalizando a legitimidade da actividade dos profissionais da saúde, obstando à formação de grupos antagónicos e rivais despoletadores de violências, promovendo acções de pacificação entre conceIhos desavindos e fiscalizando a moralidade pública. A promoção da observância das leis e dos decretos régios e a punição exemplar dos desobedientes era também sua obrigação natural.

Aos Corregedores eram também cometidas atribuições no âmbito do fomento florestal e frutícola, de acordo com a aptidão das regiões onde exerciam o mandato. Não raro, cartas régias especiais encomendavam-lhes determinadas medidas de incremento agrícola, nomeadamente no campo da cerealicultura, da criação de cavalos, da construção ou beneficiação da rede viária e até do repovoamento de lugares desertificados.

No campo da administração municipal propriamente dita, cabia ao Corregedor não só convocar e presidir às eleições para os mais importantes cargos concelhios e fazer listagem das personalidades mais aptas para os postos de topo, bem como decidir sobre a bondade de eleições de almotacés mas também fiscalizar os diversos aspectos da acção governativa dos Vereadores municipais e estimular o seu zelo para a manutenção eficaz das infra-estruturas da comunidade (calçadas, pontes, chafarizes, caminhos, casas do Concelho).

Não pertencendo à governança municipal, o Corregedor comparecia na Câmara em momentos cruciais da vida concelhia ou nacional e a Coroa, para além de exigir o

(23) Portaria de 11 de Fevereiro de 1813. 
seu parecer para despachar requerimentos das Vereações, frequentemente encomendava-Ihe serviços que iam para além das competências definidas nas Ordenações do Reino: por exemplo, coadjuvação em assuntos militares, defesa dos direitos da Coroa perante atitudes abusivas dos Donatários da mesma Coroa(24) ou até dos Bispos das Dioceses a pretexto da defesa de antigos privilégios. (25)

Assim sendo, parece importante sublinhar desde já que, embora a lei fundamental dos Corregedores se mantivesse válida enquanto as Ordenações o foram, ao longo dos tempos verificou-se uma importante evolução nas suas competências no sentido do alargamento progressivo do seu campo de intervenção na vida local em geral e na esfera das atribuições municipais tradicionais e até de tutela de outros magistrados. Tal processo será mais visível a partir do pombalismo mas é-lhe seguramente anterior.

Reconhecidos como os principais magistrados da Comarca(26) e nessa medida como mandatários por excelência da pretendida modernização administrativa, a resolução de 1 de Outubro de 1764 dá-lhes jurisdição para receber as queixas contra os capitães-mores á ordem do General da Província, por turno com os Provedores e os Juízes de Fora. Ainda cumulativamente com Provedores e Juízes de Fora, a carta de lei de 14 de Outubro de 1773 concedia-lhes, quando em correição, o conhecimento dos processos de adjudicações de casas, terrenos e prédios.

Nesta linha ascensional, é-lhes reconhecido o direito exclusivo de publicar leis e passar ordens às Câmaras das cidades e vilas principais (27) e bem assim a incumbência de presidir às eleições para os Superintendentes das Coudelarias e até de os substituir nas vacaturas ou nos seus impedimentos. Substituíam também os ministros do primeiro banco quando estes se retiravam para dar «residência». (28)

Já próximo do final do ministeriado pombalino, abriu-se-lhes um campo não totalmente novo mas sintomático das novas relações do Estado com a Igreja: foram incumbidos de visitar anualmente os conventos de Religiosos para indagar se tinham cárceres privativos onde tiranizavam os irmãos. ${ }^{(29)}$

A complexidade progressiva da vida das comunidades exigia novas instituições no Centro a que naturalmente era preciso corresponder na Periferia. Neste processo, mais uma vez, os Corregedores estiveram na primeira linha: criada a Intendência Geral da Polícia de Lisboa com jurisdição alargada a todo o Reino, ${ }^{(30)}$ foi pedido aos

\footnotetext{
(24) decreto de 17 de Novembro de 1801.

(25) - Aviso de 20 de Março de 1782.

(26) Provisão de 10 de Março de 1764.

(27) Provisão de 12 de Outubro de 1769.

(28) Resolução de 27 de Julho de 1771 e Alvará de 8 de Fevereiro de 1775.

(29) Resolução de 2 de Maio e lei de 30 de Julho de 1775.

(30) Alvará de 25 de Junho de 1760.
} 
Corregedores que se dedicassem mais e mais ao combate à criminalidade e pela ordem de 3 de Janeiro de 1789 foram ligados organicamente à Intendência Geral da Polícia para darem parte dos crimes ocorridos na sua área. E no contexto da Guerra da Sucessão de Espanha, foi-lhes confiado o ónus de sequestrar os bens dos milicianos desertores e era a eles que se deviam dirigir os Generais em chefe para a requisição de bagageiros e carreiros. ${ }^{(31)}$ Aliás, eram obrigados a proceder contra os Juízes ordinários que não cumprissem as ordens dos Inspectores de Transportes. ${ }^{(32)}$

Nem a área da saúde Ihes era estranha: competia-lhes dar posse e fiscalizar a actividade profissional do delegado do Físico-Mor do reino nas terras de sua jurisdição. ${ }^{(33)} \mathrm{E}$ até os serviços tradicionais dos Provedores, como a protecção a menores eram invadidos: em 1811 foram encarregados de distribuir pelos Párocos os menores desamparados da sua circunscrição. ${ }^{(34)}$

Reafirmando embora que os Corregedores sempre gozaram de grande prestígio e da protecção régia como agentes qualificados da centralização e como vigilantes e promotores por excelência da observância das leis e do direito, temos que reconhecer que no decorrer da segunda metade do século XVIII as circunstâncias políticas e as renovadas filosofias do Poder levaram a um notório reforço da sua intervenção na organização da vida das comunidades, de modo a convertê-lo, como diz José Viriato Capela, «no mais importante interlocutor do governo com os povos e administrações locais e territoriais». ${ }^{(35)}$ A sua acção concreta torna-se bem visível a quem se der ao trabalho de examinar as correições e os respectivos capítulos. ${ }^{(36)}$

Na verdade, a prática das correições remonta a épocas muito anteriores em relação àquela que aqui estudámos e não era um exclusivo dos Corregedores. ${ }^{(37)}$ Mas a força das observações escritas anualmente pelo Corregedor impõe-se agora aos responsáveis pelas Câmaras como uma norma de aferição da sua própria eficácia governativa.

Deve acrescentar-se, aliás, que a dignificação da justiça e a defesa dos respectivos oficiais foi expressamente desejada pelo Poder político: de facto, o alvará de 24 de Outubro de 1764 considerava crime de lesa-majestade a resistência aos magistrados.

(31) Portarias de 12 de Junho de 1809 e de 9 de Maio de 1812.

(32) Portaria de 14 de Maio de 1812.

(33) Alvará de 22 de Janeiro de 1810.

(34) Portarias de 1 de Março de 1811, de 8 de Agosto de 1811 e 8 de Maio de 1812

(35) CAPELA, José V., A Câmara, a Nobreza e o Povo do Concelho de Barcelos, Barcelos, 1989, p. 241.

(36) Ver CAPELA, José V., Política de Corregedores. A actuação dos Corregedores nos municípios minhotos no apogeu e crise do Antigo Regime(1750-1834), Braga, 1997.

(37) Nos finais do século XVI, Juiz, Vereadores, Procurador da Cidade e Escrivão da Câmara do Porto faziam correição anual pelos 12 lugares do Termo da Cidade aos quais não chegava a acção dos almotacés urbanos. (AHMP, Próprias, livro 3, fls. 261-264. 
Deve interpretar-se no mesmo sentido tanto a disposição que proibia aos Vereadores que serviam de Juízes pela Ordenação o final conhecimento de todas as causas cíveis e criminais ${ }^{(38)}$ como a determinação que mandava anexar aos Juízes de Fora os Juízes dos Órfãos leigos que não tivessem proprietário.(39)

\section{A «residência»: sindicância e avaliação do desempenho}

Mas, perguntar-se-á, os Corregedores ter-se-ão convertido então em supermagistrados intocáveis e inatingíveis? Quando os ofícios de Corregedor e Provedor se concentravam na mesma pessoa, os seus poderes eram, de facto, de amplo espectro. Prepotência e abusos de poder, sempre os houve, mesmo em ofícios de pouca substância. Mas havia mecanismos dissuasores de arbitrariedades. Por um lado, tiveram que suportar durante muito tempo a concorrência, a atenção e talvez a inveja dos Juízes de Fora e até dos Provedores. Mas o mais incómodo era que no fim do seu mandato trienal tinham que se sujeitar à residência que, no fundo, era uma espécie de sindicância e de avaliação do seu trabalho desenvolvido ao longo do triénio uma verdadeira correição ao corregedor.

Como é que se processava a "residência» e sobre que matérias é que incidia?

Um mês ou dois antes de completar o triénio, o Oficial devia fazê-lo saber ao Desembargo do Paço. Logo este Tribunal enviaria um Desembargador ou, mais correntemente, nomearia um Oficial de graduação igual ou mais elevada que se deslocaria à cabeça da Comarca ou da Ouvidoria - o qual logo que chegasse, ordenaria ao Sindicado que se retirasse para um lugar que ele próprio lhe fixaria, distante no mínimo seis léguas. A sindicância era publicamente anunciada através do lançamento de pregões a convidar a população a comparecer perante o Sindicante, nos trinta dias seguintes, para fazer as declarações que entendesse acerca do magistrado cessante, a favor ou contra, com garantia total de que nenhum mal lhe adviria em consequência do que dissesse.

As matérias sobre as quais os declarantes se podiam pronunciar contemplavam naturalmente as mais diversas matérias, mas o Legislador fixou algumas nas Ordenações que eram de inquirição obrigatória. ${ }^{(40)}$ Posteriormente, outras matérias pontuais foram sendo acrescentadas, de acordo com os decretos que o rei queria ver cumpridos. A melhor forma para o conseguir parece que era comprometer os Corregedores na sua observância, asseverando que essas novas matérias iriam fazer parte do elenco das perguntas a fazer às testemunhas e mais depoentes.

(39) Alvará de 23 de Outubro de 1813.

(38) Alvará de 5 de Setembro de 1774. 


\section{O que pensar sobre a eficácia dos juízos de residências?}

Não se conhecem estudos de fundo sobre as «residências» em Portugal, ao contrário do que sucede em Espanha. Nós próprios descobrimos indícios de que no século XVII, não obstante as queixas contra a falta de isenção e cumplicidade dos Sindicantes denunciada em Cortes, os prepotentes, pouco zelosos e incompetentes podiam ser prejudicados na sua colocação futura. ${ }^{(41)}$ Ao que parece, a eficácia era muito duvidosa no período que aqui abrangemos. ${ }^{(42)}$ Todavia, tal como Dominguez Ortiz, ${ }^{(43)}$ pensámos que o simples facto de elas existirem constituiu um freio contra a tentação de prepotência e arbitrariedade. Esse alvitre ganha mais consistência se tivermos em conta que nas residências não era apenas o desempenho do Corregedor que era devassado mas também o de todos os seus oficiais subalternos que lidavam com as pessoas no dia a dia. Se acrescentarmos que o sistema da residência se estendia a outros magistrados, como os Juízes de Fora ${ }^{(44)}$ e Juízes de Fora dos Órfãos, ${ }^{(45)} \mathrm{e}$ ainda aos Vereadores mais velhos que substituíssem os Juízes de Fora nas suas ausências ou impedimentos, ${ }^{(46)}$ estamos em presença de estruturas que poderiam ter protegido eficazmente os mais débeis contra a prepotência dos mais fortes. Mas a realidade nem sempre corresponde ao modelo.

\section{3-Os Concelhos}

Como insinuámos acima, pensámos que, entre nós, ao menos desde a Idade Média o poder local por antonomásia é o poder municipal. Mas os Concelhos eram muitos e muito diferentes entre si. Nos finais do Antigo Regime, Portugal contava mais de 800 , já o lembrámos. Após a reforma de 1836 o seu número foi abatido para

(40) Ordenaçōes Filipinas, Livro $1^{\circ}$, tit, 60.

(41) SILVA, Francisco Ribeiro, O Porto e o seu Termo ..., II vol., p.1006.

(42) É essa a posição defendida por HESPANHA, António Manuel, História das Instituições. Épocas medieval e moderna, Coimbra, 1982, p. 420.

(43) DOMINGUEZ ORTIZ, António, Historia de España - El Antiguo Régimen:Los reyes católicos y

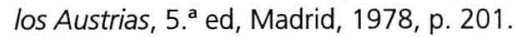

(44) Sobre residências dos Juízes de Fora de Évora, ver, Maria Teresa Couto Pinto Rios da, Absolutismo e Municipalismo. Évora (1750-1820), dact., vol. I, Lisboa, Universidade Nova, 2000, p. 153-154. Esta dissertação de doutoramento, embora chegasse às nossas mãos muito depois da redacção deste capítulo(e daí o pouco uso que dela fizemos) não deixa de ser um contributo importante para aprofundamento destas matérias.

(45) Acerca das matérias sobre as quais incidia a sindicância aos juízes dos órfãos, ver o respectivo documento publicado no nosso Filipe II de Espanha Rei de Portugal, II vol., Zamora, Fundación Rei Afonso Henriques, 2000, pp. 551-555.

(46) Alvará de 5 de Setembro de 1774. 
351. (47) Tão drástica redução significa que havia concelhos em demasia? Contrariamente ao que parece evidente, a questão não é susceptível de uma resposta do tipo sim ou não. Num sistema político representativo em que o acesso generalizado aos cargos do poder é desejável e garantido, há naturalmente limites mínimos de população e de recursos para que uma comunidade possa sobreviver organizada. É óbvio que na maior parte destes concelhos não havia homens em número e com preparação adequada para assumir rotativamente os postos da liderança municipal. Mas no Portugal moderno, o poder em qualquer nível que o consideremos, inclusive ao nível municipal, cabia a algumas famílias cujos membros se perpetuavam no exercício dos cargos, pelo que uma quantidade mínima de pessoas bastava para assegurar as principais tarefas. Por isso, centenas de concelhos minúsculos puderam subsistir durante séculos. E não obstante a sua insignificância e a sua insuficiência invencível, pela estrutura institucional e pelo tipo de funções desempenhadas pelos seus oficiais, mereciam a designação de concelhos tanto como os de maior pujança espacial, demográfica, social e económica. Nesse sentido, e só nesse, se pode falar de uma certa uniformidade dos concelhos portugueses. Mas no tipo de relacionamento deles com o poder central, na importância e na relação de forças dos concelhos entre si, as diferenças eram óbvias e as rivalidades por motivos bem fúteis também. A propósito das rivalidades, bastará lembrar que uma das obrigações do Corregedor era a de prevenir e sanar diferendos entre os concelhos da sua jurisdição. Rivais e marcados por uma tradição de individualismo. Mas é possível encontrarem-se demonstrações de interacção e apoio mútuo em circunstâncias conjunturais adversas: as comunicações que entre si estabeleciam os concelhos do litoral a dar notícias de peste ou da presença de piratas, a colaboração em acções de prevenção da pirataria, a cadeia de solidariedade que se verificou por alturas da aclamação do Duque de Bragança em 1640 nos concelhos do Norte ou na luta contra o invasor francês em princípios de Oitocentos.

Sendo diferentes, pode-se falar de uma certa hierarquização dos concelhos. Assim, desde sempre, e formalmente pelo menos desde 1591, a Câmara de Lisboa era considerada a «cabeça» das Câmaras das cidades e vilas do Reino cujo bom governo dependia do da capital, (48) o que normalmente foi bem aceite pelas demais, com alguns episódios de insubmissão por parte de algumas, nomeadamente pela do Porto. ${ }^{(49)}$ É sabido que os Concelhos de primeiro banco em Cortes (tradicionalmente Lisboa, Évora, Coimbra, Porto e Santarém) constituíam uma referência nas relações

\footnotetext{
(47) FIGUEIREDO, Fausto J. A. de, O.c., p. 12.

(48) Regimento de 30 de Julho de 1591.

(49) SILVA, Francisco Ribeiro da, O Porto e o seu Termo..., II vol., p. 829.
} 
do poder central com as Câmaras como se formassem uma espécie de "sanior pars» e exemplo incontornável para as demais. ${ }^{(50)}$ Aliás, enquanto existiram Cortes (as últimas, como é sabido, tiveram lugar em 1697) a hierarquia dos Concelhos ficava bem patente no lugar que cada um ocupava na sala da sessão se abertura. Dado o formalismo das convocatórias, avesso a novidades, é possível que um ou outro Concelho que entretanto conseguisse adquirir projecção pelos progressos demográficos ou de dinamismo económico, ficasse de fora deste quadro de prestígio e de capacidade de intervenção que as Cortes significavam.

Por conseguinte, ter a sede em cidade ou vila, gozar ou não da prerrogativa de assento em Cortes, ser ou não ser cabeça de comarca ou concelho-cabeça, ${ }^{(51)}$ pagar terças gordas ou magras ao Erário régio, ${ }^{(52)}$ dispor de abundante ou exígua população, contar muitas ou poucas casas nobres, muitos ou poucos mosteiros, são critérios utilizados de escalonamento dos Concelhos. O que significa que a maioria dos Concelhos, maioria que se contava por centenas, de jurisdição senhorial ou régia, era, de facto, de importância menor. E constitui, sem dúvida, sinal inequívoco da importância dos concelhos o ter ou não Juiz de Fora e Juiz de Fora dos Órfãos.

\section{Os Termos dos Concelhos ou os Concelhos com Termo}

Existe uma outra realidade diferencial de que raramente se fala mas que me parece que aqui não deve ser olvidada. São os termos dos Concelhos ou os Concelhos com Termo ou Alfoz como, a propósito de Coimbra, preferiu chamar-lhe o Senhor Prof. António de Oliveira. ${ }^{(53)}$ Penso que teria todo o interesse um estudo comparado não só sobre a extensão dos termos dos concelhos mas das relações que as vilas ou cidades cabeças de concelho mantinham com o seu termo. É que podemos estar perante verdadeiras circunscrições administrativas aglutinadoras, ainda que à força, de vários e antigos concelhos. Exemplificarei rapidamente com o caso do Porto que se não é único é, pelo menos, insólito. É que D. João I submeteu ou confirmou a submissão à Câmara do Porto os sete Julgados envolventes que coincidem em grande parte com o que hoje em dia se chama Grande Porto. Eram eles: Bouças (Matosinhos), Maia (com Azurara), Refojos de Riba d'Ave (Santo Tirso), Aguiar de

(50) Elvas não descansou enquanto não conseguiu assento nesse primeiro banco - o que conseguiu em 1642.

(51) O Procurador de Barcelos aduz esse argumento para reivindicar mais poderes. CAPELA, José V., A Câmara, a Nobreza e o Povo ... p. 105.

(52) Ver CAPELA, José Viriato, O Minho e os seus Municípios..., Braga, 1995, p. 56.

(53) OLIVEIRA, António de, A vida económica e social de Coimbra de 1537 a 1640, 2 vol.s, Coimbra, Faculdade de Letras, 1971-1972. 
Sousa, Penafiel, Gondomar e Melres, Gaia e Vila Nova. Submeteu quer dizer isso mesmo: passaram a estar dependentes do Senado da Câmara do Porto não só sob o ponto de vista económico e de organização militar mas também administrativamente. A ponto de cada um deixar de ter Câmara própria e passar a ser governado por um Ouvidor, eleito local e anualmente, mas aprovado e empossado pela Câmara do Porto, o qual respondia perante a mesma Câmara. Quer dizer: o termo do Porto assim alargado passou a constituir uma espécie de senhorio exercido não por um Donatário leigo ou eclesiástico, mas por uma cidade ou melhor, pelo Senado Municipal dessa Cidade.

Deveremos chamar Concelhos a cada um destes espaços? Na verdade, como dissemos, não dispunham de Câmara. Mas elegiam os seus oficiais: um ouvidor, um meirinho, às vezes um procurador e em certos casos beneficiavam mesmo de almotacé. E também de juiz dos órfãos, cargo que frequentemente se transmitia pela via da hereditariedade ou mesmo da venalidade. A terminologia da época pode ser um bom indicador. Ora se inicialmente a palavra «julgado»(54) era a mais utilizada, a partir do séc. XVII usam-se as duas indiscriminadamente com preferência progressiva pela segunda, isto é, pela designação de Concelho.

Que tipo de relações se estabeleciam entre a cidade e o termo?

Relação de dependência, com tensões e conflitualidades que bem se podem adivinhar.

Mas dentro do Termo existiam espaços dotados de isenções e imunidades, os coutos e honras. Sobre eles a Câmara do Porto tentou exercer o domínio possível, de acordo com as épocas e o zelo dos Vereadores por um lado e dos Corregedores da Comarca por outro. De maneira geral pode dizer-se que a Câmara exerceu a jurisdição no crime mas no cível foi obrigada a, repetidamente, reconhecer a autonomia dos senhores, sobretudo dos mosteiros. Uma grande vitória da centralização foi a conseguida contra o Balio do Couto de Leça o qual, na segunda década de seiscentos tendo tentado formar Câmara com Vereadores e demais oficiais, foi impedido disso por decisão do Tribunal.

Mas parece evidente por outros estudos que as honras e os coutos disseminados pelo Reino dispunham de organização institucional mínima e autónoma.

Creio, por isso, poder afirmar com verdade que um conjunto de instituições básicas aproximaram modelarmente os concelhos uns dos outros, independentemente de ser grande ou pequeno o seu espaço.

(54) Segundo António Manuel HESPANHA, julgado era uma »circunscrição administrativo-judicial decalcada sobre uma unidade geográfica natural ou tradicional...». História das Instituições. Épocas medieval e moderna, Coimbra, Almedina, 1982, p. 150. 
Que instituições básicas?

Um (ou dois) Juízes ordinários (ou um de fora)

Vereadores (de seis a um, conforme os casos, sendo de três ou dois os números mais vulgares. Seis apenas em Lisboa).

Procurador do Concelho e Tesoureiro

Procurador(es) dos Mesteres quando o dinamismo dos ofícios ou mesteres o justificava.

\section{Escrivão}

Mas que poderes em concreto se adequaram aos Concelhos?

Se pensarmos nos Concelhos de jurisdição régia que tinham por cabeça uma cidade ou vila de razoável dimensão, os poderes do senado municipal poderiam organizar-se e desenvolver-se do seguinte modo:

Poder executivo de administração e de governo - esse era o primordial e principal poder que era também a principal obrigação: cuidar do «regimento» da terra e das obras do concelho de modo que os moradores dela pudessem bem viver.

Alguns Vereadores tinham desse poder um entendimento lato, quase tão lato, à sua escala, como o poder dos Reis em relação ao reino. Embora noutro nível, o da representação, lembremos que em 1630 os Vereadores do Porto, congregados em corpo de Câmara, ousaram recomendar ao Bispo da Diocese que enquanto esperava que os bailadores acabassem sua dança na procissão do Corpo de Deus não tomasse cadeira diante deles mas buscasse assento no interior de uma casa contígua até que a dança acabasse e a procissão pudesse prosseguir. Na mesma linha, o dominicano Frei Miguel Chamorro chama aos Vereadores portuenses «pais desta cidade e seu povo»(55) usando uma expressão que evoca aquele aforismo já presente em Diogo Lopes Rebelo do Rei como pai dos súbditos e da pátria.

Os outros poderes decorriam deste poder primordial.

Assim, o poder legislativo - ou seja, promulgação de posturas e acórdãos de acordo com os costumes antigos da cidade ou vila, ou por força de novos condicionalismos desde que cumprissem «ao prol e bom regimento da terra»(56) e desde que fossem previamente submetidos á aprovação da Junta dos cidadãos.

Na mesma lógica dispunham de poder económico. Cumpria aos vereadores (e em parte aos almotacés por eles nomeados) organizar mercados e feiras (as feiras francas dependiam da aprovação prévia do monarca), fixar preços dos produtos pro-

(55) SILVA, Francisco Ribeiro da, O Porto e seu Termo..., pp. 416-417.

(56) Ordenações Filipinas, Livro, I, tit. 66, § 28. 
curando um equilíbrio sempre difícil entre os interesses dos vendedores e os dos compradores e velar pelo seu cumprimento, emitir licenças de comércio, atrair fornecedores das mercadorias (criação de infraestruturas portuárias, boa conservação dos caminhos e vias, das pontes etc.) O poder económico passava pela administração correcta dos bens do Concelho. Bens móveis como barcas de passagem de rios, e imóveis como quintas e maninhos e ainda direitos de tipo senhorial como os foros a pagar pela construção de casas em solo considerado propriedade municipal. Eram-lhes igualmente cometidas recomendações de fomento de riqueza, por meio de programas de florestação e de aproveitamento agrícola.

O poder financeiro de que dispunham era diminuto, significando pouco mais do que a colaboração com as ordens do poder central. Mas o poder central não podia dispensar a colaboração do poder local na recolha das sisas e donativos ou contributos especiais, pela razão simples de que não dispunha nem parece ter alguma vez querido dispor de pessoal para organizar a cobrança directa. Para aliciar os concelhos, tornou-os participantes (parceiros) nos apuros efectuados, através da negociação do cabeção das sisas em tempos que remontam a D. Sebastião.

Capacidade eleitoral - eleição trienal dos governantes locais (isto é, dos que haviam de servir os diversos cargos da governança municipal - juízes ordinários, vereadores, procurador do Concelho, tesoureiro. Poder tutelado pelo Corregedor. Poder de eleger os representantes ou Procuradores às Cortes. Poder de eleger os oficiais do abastecimento que eram os Almotacés. Eleição fechada e limitada. Poder e dever de eleger / nomear oficiais necessários ao bom andamento da vida quotidiana.

Poder judicial - Limitado mas importante, nomeadamente na resolução de pequenos conflitos de que é feita a vida de uma cidade ou vila. Que exerciam os vereadores juntamente com o Juiz de Fora e com os juízes ordinários, para o que davam audiência duas vezes por semana. O pelourinho e a cadeia pública municipal remetem para o poder judicial municipal.

Poder policial — Segurança e defesa das populações foi uma preocupação de todos os tempos. Assegurada pelos quadrilheiros, meirinhos e alcaides pequenos, ofícios bem distintos na sua origem mas que coincidiam nos objectivos e missões.

Poder militar - Nas cidades e vilas principais em épocas de crise formava-se uma Companhia de nobres e cidadãos capitaneada pelo Vereador mais velho e era no âmbito municipal que se organizavam as Companhias de Ordenanças.

\section{4 - As Freguesias e Lugares}

O Concelho não era a fronteira última da divisão administrativa. Integradas nos concelhos, mas sem constituírem sempre corpo místico com eles, espalhavam-se os 
milhares de freguesias que dispunham de organização administrativa própria ainda que rudimentar. Há que fazer distinção entre os oficiais privativos das paróquias, eleitos localmente e aí empossados e os que, também eleitos na localidade, tomavam posse dos cargos nas Câmaras e agiam em nome delas. Isto nos tempos finais da época moderna e sem prejuízo de, por vezes, o mesmo oficial assumir ambos os papeis. ${ }^{(57)}$ Os oficiais próprios das aldeias eram designados de forma diversa conforme as terras, mas os nomes mais vulgares no Entre Douro e Minho parecem ser os de juiz do subsino ou simplesmente eleito e são eles que representam a localidade em actos de interesse comunitário, como por exemplo, o aforamento dos baldios. Quanto aos segundos, são designados como jurados, quadrilheiros e coudeis da montaria ou coudeis da raposa.

Embora não abundem estudos sobre a organização administrativa das freguesias, algo mais poderemos acrescentar sobre estes cargos. A eleição era realizada, em princípio em todas as freguesias, no fim de cada ano, sabendo-se que cada um servia durante um ano, com excepção dos quadrilheiros cujo mandato se exercia por três anos. As freguesias mais povoadas elegiam dois ou três jurados. Assim era no termo do Porto mas noutras terras o mecanismo era diferente.

Por exemplo, em 1758, em S. João de Bastuço, na Comarca de Barcelos, os moradores reuniam na presença do Pároco para eleger juiz do subsino e dois homens da fala. (58) O Juiz da vintena (ou juiz pedâneo) e seu escrivão da freguesia de Santo Aleixo, concelho de Monforte, eram nomeados pela Câmara tal como o de Nogueira, em Bragança, era nomeado pelo Juiz de Fora. ${ }^{(59)}$

A nomeação para os ofícios administrativos da freguesia não era muito apetecida porque os benefícios eram nulos e os incómodos podiam ser de monta. Por outro lado, adquirir um privilégio que isentasse de servir nos cargos paroquiais era fácil. Pelo que podia suceder uma destas duas situações: ou os ofícios eram desempenhados pelos mais débeis ou não havia quem servisse por todos serem privilegiados. A mais corrente era a primeira e assim se defraudavam as intenções do legislador que pretendia ver nas funções os mais capazes. Mas não faltam no Entre Douro e Minho exemplos da segunda em que, por serem todos privilegiados, os moradores não tiveram outra solução senão servir rotativamente sem distinguir entre privilegiados e devassos. ${ }^{(60)}$

(57) CAPELA, José V. , A Câmara, a nobreza e o povo...,p. 114-115.

(58) ANTT, Dicionário Geográfico, (Memórias Paroquiais), Livro 6, fl. 450. Sobre estes cargos. Ver CAPELA, José V., A Câmara, a nobreza e o povo ..., p. 121.

(59) ANTT, Dicionário Geográfico, (Memórias Paroquiais), Livro 2, fl. 288 e L. 25, fl. 202.

(60) SILVA, Francisco Ribeiro da, O Porto e o seu Termo..., II vol., p.681. 
Seriam importantes as funções e os poderes das autoridades das aldeias? Sem dúvida! Apesar de maciçamente analfabetos (no Termo do Porto no século XVII não mais de $5 \%$ eram capazes de assinar o seu nome), os jurados, tal como os juízes da vintena configurados nas Ordenações do Reino, dispondo de alçada proporcional ao número de habitantes, julgavam e sentenciavam sem apelo nem agravo pequenas contendas entre moradores, em processo verbal e sumário. Competia-lhes ainda aplicar e executar coimas por danos provocados por gados. Estava fora da sua alçada o julgamento de causas sobre bens de raiz. E não se poderiam esquivar a colaborar com as autoridades concelhias nos diversos aspectos da administração, às vezes contra os seus próprios interesses.

As atribuições dos quadrilheiros das aldeias não diferiam muito dos da cidade: deviam prender todos os malfeitores, especialmente os que andassem fugidos à justiça, procurariam estar bem informados sobre eventuais furtos cometidos na sua terra e sobre seus receptadores bem como acerca de movimentações de pessoas estranhas. As casas de jogo e de passe, os infractores da moral pública, a existência de bruxas e feiticeiras tudo devia denunciar ao Juiz. Em nome da quietude e dos bons costumes.

Quanto aos coudeis da montaria ou juízes da raposa diremos, antes de mais, que se trata de uma instituição muito vulgar nas freguesias do termo do Porto mas que não temos visto referenciada para outros lugares. As suas funções, mais do que ligadas ao controlo dos obrigados a sustentar cavalo, exerciam-se no âmbito da protecção contra arremetidas de animais selvagens. Concretamente deviam pôr-se de atalaia contra raposas, lobos e outros bichos que pudessem causar dano aos moradores e suas criações. ${ }^{(61)}$

Resumir-se-ia a estas três magistraturas o cuidado da organização da vida quotidiana nas aldeias? Essas eram as que asseguravam a ligação orgânica da aldeia ao concelho. A julgar pelo que está averiguado para o Concelho de Barcelos, as freguesias criavam os seus próprios órgãos e governavam-se internamente através deles.

Perante estas informações, uma conclusão parece impôr-se: para além da realidade institucional das Comarcas e dos Concelhos, existia insofismável a realidade das paróquias com as suas instituições próprias de cuja eficácia nem sempre ficou memória nos Arquivos. Mas a parcimónia das informações não esconde que os habitantes dos lugares e povoados do reino, dentro dos seus microcosmos, se sabiam reger e governar por si próprios.

(61) AHMP, Copiador do Governo, Livro 2057, fl.79v-81 (24 de Julho de 1784) 


\section{Conclusão}

Duas conclusões - a primeira é que, olhando para o passado, a organização do poder local obedeceu a várias escalas mas em qualquer delas mostrou-se suficientemente idóneo e capaz de organizar a vida das populações, ainda que na época moderna ( quer foi aquela que aqui tratámos) o poder central tenha desenvolvidos mecanismos e instituições de tutela desse mesmo poder. Um dos objectivos régios ao colocar agentes seus espalhados pelo Reino terá sido o de tentar atenuar ou calibrar o eventualmente progressivo poder das famílias dominantes que tenderam a perpetuar-se no poder municipal, especialmente nas cidades e vilas mais importantes. Duvido que se tenha pretendido alguma vez evitar a formação dessas elites. É minha convicção que Corregedores, Provedores e Juízes de Fora se assumiram como agentes do poder central mas a sua eficácia em cada caso, para além das suas capacidades pessoais, teve a ver com circunstâncias e conjunturas diversas.

A segunda é que assim como não concebo como teria sido possível no passado a organização da vida quotidiana das comunidades sem o forte contributo dos agentes locais, nascidos e criados no seio dessas mesmas comunidades que eram os concelhos e freguesias, também não entendo como seja possível no futuro prescindir desse contributo. E quanto mais democrática for a organização estrutural do país, maiores vantagens poderão advir ao poder local. Isto porque em democracia, quem detém o poder é quem os governados quiserem e enquanto o quiserem.

É óbvio que não pode estar em causa um poder central prestigiado e competente mas suficientemente lúcido para perceber que um poder local, igualmente prestigiado e competente e dotado de meios, pode ser a chave do bem-estar e da felicidade quotidiana das populações - que, no fundo, é o que mais importa. 
Investigaçāo

Coimbra.

Imprensa da Universidade 